\title{
Renal Complications of Sickle Cell Syndrome in Southern Iran
}

\author{
Mahdi Shahriari, ${ }^{1}$ Mohammad-Hossein Fallahzadeh, ${ }^{2}$ Leila Malekmakan,, ${ }^{3,}$ and Sayyed-Yousef
}

\author{
Mojtahedi ${ }^{4}$ \\ ${ }^{1}$ Department of Pediatrics, Pediatric Hematology Division, Hematology Research Center, Shiraz University of Medical Sciences, Shiraz, Iran \\ ${ }^{2}$ Department of Pediatrics, Pediatric Nephrology Division, Shiraz Nephro-Urology Research Center, Shiraz University of Medical Sciences, Shiraz, Iran \\ ${ }^{3}$ Shiraz Nephro-Urology Research Center, Shiraz University of Medical Sciences, Shiraz, Iran \\ ${ }^{4}$ Department of Pediatrics, Pediatric Nephrology Division, Ziaeian Hospital, Tehran University of Medical Sciences, Tehran, Iran \\ "Corresponding author: Leila Malekmakan, Department of Community Medicine, Shiraz Nephro-Urology Research Center, Shiraz University of Medical Sciences, Shiraz, Iran. \\ Tel: +98-7132127300, E-mail: malekl@sums.ac.ir
}

Received 2017 February 15; Revised 2017 April 30; Accepted 2017 July 29.

\begin{abstract}
Background: In spite of many reports on sickle cell disease, to our knowledge frequencies of nephrologic complications are not well defined especially in sickle thalassemia. The aim of this study was to assess the nephrologic complications of sickle cell syndrome. Methods: This is a cross sectional study, including all of the patients with sickle cell syndromes (97 cases) in hematology-oncology clinics of Shiraz University of Medical Sciences. A complete history taken and physical examination was performed. Blood and urine samples were sent for different tests including micro albuminuria and Cystatin C to measure glomerular filtration rate.

Results: Ninety seven patients with mean age of $8.5 \pm 3.4$ years ( $55.4 \%$ males) were divided into three groups; 30 cases with sickle cell disease, 31 patients with sickle cell trait, and 36 cases with sickle thalassemia. Enuresis was present in 20 (22.9\%) patients $>5$ years. Significant proteinuria was not observed, but micro albuminuria was found in $14(14.4 \%)$ patients. GFR was in normal range when calculated with creatinine clearance, but glomerular hyper filtration was present in $5.2 \%$ by Cystatin C formula. Mean serum creatinine was in low normal range $(0.5 \pm 0.1)$ but mean serum Cystatin $\mathrm{C}(0.9 \pm 0.1)$ was higher than the normal range especially in $\mathrm{S} \beta$ patients $(\mathrm{P}=0.023)$.

Conclusions: In contrast to other reports, at least in the first two decades of life significant renal complications including renal failure and proteinuria were unusual in our patients with sickle cell syndrome.
\end{abstract}

Keywords: Sickle Cell Anemia, Sickle Trait, Sickle Thalassemia, Micro-Albuminuria, Glomerular Filtration Rate

\section{Background}

Sickle cell disease (SCD) is one of the most common genetic causes of morbidity and mortality in the world, especially in the central regions of Africa with an estimated 1 out of 500 births in African Americans (1-5). It is usually caused by inheritance of the sickle $\beta$ globin gene, either in homozygous form (hemoglobin SS), Sickle trait (SA) or in combination with hemoglobin $\mathrm{C}(\mathrm{SC}), \beta$-thalassemia ( $\beta$ thalassemia) or several less common hemoglobin variants (1). Sickle cell anemia and the related hemoglobinopathies (including sickle $\beta$ thalassemia which is common in southern Iran) causes micro vascular occlusion, which is manifested in most organ systems with a large spectrum of renal abnormalities (5). About $4 \%-12 \%$ of these patients will progress to end-stage renal disease (ESRD) and survival is significantly decreased in sickle cell patients who develop renal failure $(5,6)$.

The genitourinary tract is most commonly affected by hematuria, urinary tract infection, and priapism but other more serious complications like testicular infarction and renal medullary carcinoma have also been identified (2).
The patients have impaired urinary concentrating ability, supra normal proximal tubular function, defects in urinary acidification and potassium excretion (5). Young SCD patients have supra normal renal hemodynamics with elevations in both effective renal plasma flow and glomerular filtration rate (GFR). These changes decrease with age as well as following the administration of prostaglandin inhibitors (5-7).

Micro albuminuria, an early manifestation, has been reported in $30 \%-60 \%$ in SCD patients $(5,6)$. Also proteinuria, which begins early in life and is associated with severity of disease, was seen in $20 \%-25 \%$ of SCD patients. It may progress to nephrotic syndrome as a rare condition in $>4 \%$ of SCD patients $(3,8)$. Early detection of proteinuria may allow therapy to prevent progressive renal insufficiency (4).

To our knowledge there is not enough information about frequency of proteinuria, micro albuminuria, and other renal manifestations in subtypes of SCD especially in $\mathrm{s} \beta$-thalassemia. Therefore this study was carried out in order to fill such a gap. 


\section{Methods}

\subsection{Study Population}

This is a cross sectional analysis of all of the patients with sickle cell syndromes in hematology-oncology clinics affiliated to Shiraz University of Medical sciences with referral patients from most Southern provinces of Iran. From January 2013 till April 2014 ninety seven patients were enrolled in the study. The inclusion criteria were age $<18$ years and documented sickle cell anemia, sickle- $\beta$ Thalassemia or sickle trait. Excluding criteria were presence of any unrelated renal disease or incompliance.

\subsection{Data Collection}

A complete history was taken and physical examination performed in all the patients. Questions were asked about different urinary symptoms including; dysuria, polyuria ( $>4 \mathrm{~mL} / \mathrm{kg} / \mathrm{hr}$ ), frequency, edema, stone passing, nocturia, enuresis, and history of hospital admission. Complete physical examinations including measurement of weight, height, blood pressure level was done. Polyuria and urinary frequency were reported by the parents. For every patient urine samples were taken for micro albuminuria, specific gravity, and urinalysis (U/A). Also a blood sample for complete blood count (CBC), Cr, and cystatin $\mathrm{C}$ was taken.

CBC was done on an oxalated $2 \mathrm{~mL}$ blood sample by a (Sysmex- K 21 model), serum Cr was measured from clot sample by Jaffe method, serum cystatin $C$ was measured in clot sample by ELISA method. Urine micro albumin was checked with Minineph by nephlometric method using Binding site kit.

\subsection{Definitions}

Enuresis was defined as nocturnal or diurnal urinary incontinence at least 2 times/week after age of 5 years. Height was measured in standing position by Seca instrument and weight by Balas Digital instrument. Blood pressure was checked twice with a 10-minute interval and by one physician, using mercury sphygmomanometer and the mean value was recorded. Prehypertension (preHTN) was defined as systolic or diastolic pressure between 90 to 95 percentile for age and sex of the patients. Hypertension (HTN) was defined as systolic or diastolic pressure over 95 percentile for age and sex of the patients. Microalbuminuria was described to be abnormal if it was $>30 \mathrm{mg} / \mathrm{dL}$. Glomerular filtration rate (GFR) was measured by Cystatine $\mathrm{C}$ formula as the following GFR $=-4.32+(80.35 /$ Cystatine $\mathrm{C})$.

\subsection{Ethical Consideration}

All procedures performed in this study were in accordance with the ethical standards of Shiraz University of Medical Sciences research ethics committee; and with the Helsinki declaration standards. Informed consent was obtained from parents of all patients included in this study.

\subsection{Statistical Analysis}

The statistical analysis of the data was performed using statistical package for social sciences version 18 (SPSS Inc, Chicago, IL, USA). The results related to the continuous variables are presented as mean $\pm S D$ and those related to the quantitative or categorical data are shown as percentage and frequency. Statistical analyses were performed by Chi-square analysis (for categorical variables in different three groups as sex, blood pressure status, and some symptoms), t-test (for continuous variables in two groups as difference of mean age of the patients with microalbuminuria and in those without microalbuminuria, also in patients with enuresis and in those with no enuresis), Pearson coefficient (for relation of two continuous variables as microalbuminuria and serum $\mathrm{Cr}$, also microalbuminuria and Cystatin C levels), and ANOVA test (for continuous variables in three different groups as age, height, weight, disease duration, and some symptoms). P value $<0.05$ was considered significant.

\section{Results}

Overall 97 patients with age range of 3 to 18 years (mean age $8.8 \pm 3.4$ years) were included in the study of whom 54 patients (55.4\%) were male with male/female ratio 5.5:4.5. Thirty six patients had sickle thalassemia ( $\beta$ group), 31 patients had sickle trait (SA group), and 30 cases had sickle cell anemia (SS group). Height for age percentile was in normal range for $84.5 \%$ while weight for age percentile was in normal range of $79.4 \%$. There was no significant difference within groups in variables $(\mathrm{P}>0.05$, Table 1$)$ except in disease duration; it was $5.4 \pm 3.5$, that was lower in sickle trait group versus $S \beta$ and SS groups; $3.9 \pm 2.3$ vs $5.7 \pm 3.9$ and $6.4 \pm 3.8(\mathrm{P}=0.018)$.

Mean systolic blood pressure in all study groups was $95.0 \pm 9.9$ (range $=80-130$ ) $\mathrm{mmHg}$ and mean diastolic blood pressure was $66.7 \pm 7.5$ (range $=55-80)$ $\mathrm{mmHg}$. There was no significant difference between different groups $(\mathrm{P}=0.758$ for systolic blood pressure and $\mathrm{P}$ $=0.192$ for diastolic blood pressure). There was a significant positive correlation between age and systolic blood pressure $(\mathrm{P}=0.002, \mathrm{r}=0.317)$. PreHTN was detected in18.6\% of our patients (18 cases) and $11.3 \%$ of all patients (11 cases) had HTN. As shown in Table 2 the prevalence of preHTN and 
Table 1. Distribution of the Base Line Characteristics in Patients with Sickle Syndrome

\begin{tabular}{|c|c|c|c|c|c|}
\hline \multirow[t]{2}{*}{ Characteristics } & \multirow[t]{2}{*}{ Total, $\mathbf{n}=\mathbf{9 7}$} & \multicolumn{3}{|c|}{ Study Groups } & \multirow[t]{2}{*}{ P Value } \\
\hline & & Sickle Thalassemia, $n=36$ & Sickle Trait, $\mathbf{n}=31$ & Sickle Cell Disease, $\mathbf{n}=\mathbf{3 0}$ & \\
\hline Age (Years), Mean $\pm S D$ & $8.8 \pm 3.4$ & $8.6 \pm 3.9$ & $8.3 \pm 2.3$ & $9.6 \pm 3.8$ & 0.277 \\
\hline Sex (Male), n (\%) & $54(55.7)$ & $21(58.3)$ & $19(61.3)$ & $14(46.7)$ & 0.521 \\
\hline Height $(\mathrm{cm})$, Mean \pm SD & $126.7 \pm 17.0$ & $124.7 \pm 17.4$ & $127.2 \pm 14.8$ & $129.4 \pm 18.9$ & 0.535 \\
\hline Weight $(\mathrm{Kg})$, Mean \pm SD & $25.8 \pm 9.1$ & $24.9 \pm 8.8$ & $26.7 \pm 9.9$ & $26.1 \pm 8.8$ & 0.711 \\
\hline Disease duration (Years), Mean \pm SD & $5.4 \pm 3.5$ & $5.7 \pm 3.9$ & $3.9 \pm 2.3$ & $6.4 \pm 3.8$ & $0.018^{\mathrm{a}}$ \\
\hline
\end{tabular}

${ }^{\mathrm{a}}$ LST test as a post hoc test showed: sickle trait group had lower disease duration than the other groups $(\mathrm{P}=0.007, \mathrm{P}=0.036)$.

HTN had no significant differences between groups $(\mathrm{P}>$ 0.05).

Frequency of urinary and renal characteristics is shown in Tables 3 and 4, with no significant change in urinary symptoms between groups $(\mathrm{P}=0.05)$. Hypercalciuria was detected in $16.5 \%$ (16 cases), and $2.1 \%$ ( $2 \mathrm{~S} \beta$ patients) reported the history of renal stone. Hematuria was detected in only one SS group patient (1\% of all patients). Polydipsia, polyuria, frequency, and dysuria were seen in $19(19.8 \%)$ patients, 41 (42.3\%) patients, 5 (5.2\%) patients, and $5(5.2 \%)$ patients, respectively. And also nocturia was reported in $30.9 \%$ (30 cases) of our patients. All variables tmentioned above, had no significant relation with age $(\mathrm{P}=0.05)$. But enuresis was present in 20 out of 87 (23\%) patients who were $>5$ years old. Mean age of the patients with enuresis was $7.8 \pm 2.2$ years while it was $9.9 \pm 3.2$ years in those with no enuresis $(\mathrm{P}=0.007)$.

Glomerular hypofiltration (GFR by Cystatin C $<60$ ) was present in $5.2 \%$ of the patients. Mean serum $\mathrm{Cr}$ in our patients was in low normal range $(0.5 \pm 0.1)$ but mean serum Cystatin $\mathrm{C}(0.9 \pm 0.1)$ was higher than normal range especially in $\mathrm{S} \beta$ patients $(\mathrm{P}=0.023)$.

Proteinuria was not found by dipstick, but mean of the urine microalbumin in all patients was $27.7 \pm 7.6$ (range $=$ 0 - 235). It was $11.1 \pm 4.4$ (range $=0$ - 48.9) in SS group, $46.1 \pm$ $15.2($ range $=0-235)$ in SA group, and 10.2 $\pm 3.8($ range $=0-$ $46)$ in $\mathrm{S} \beta$ group, $(\mathrm{P}=0.901)$. Four of $29(13.3 \%)$ patients in SS group; $5 / 32$ (16.6\%) of SA group; and 5/32 (15.6\%) in $S \beta$ group had microalbuminuria. Mean age of the patients with microalbuminuria was $7.95 \pm 3.2$ years as compared to $8.9 \pm$ 3.5 years in those without microalbuminuria $(\mathrm{P}=0.464)$. There was no significant correlation between microalbuminuria and serum $\mathrm{Cr}$ levels $(\mathrm{P}=0.594)$; and also microalbuminuria and Cystatin $\mathrm{C}$ levels $(\mathrm{P}=0.07)$

\section{Discussion}

To our knowledge this is the first study that compares renal function and different aspects of renal involvement in the $\mathrm{S} \beta$, SA, and SS anemia. There are different renal manifestations in SCD patients, from painless hematuria to renal failure (5). Due to improvement in the management of SCD in recent decades, which led to a significant increase in the life expectancy of patients, a greater rate of genitourinary complications, is expected $(3,5)$. Bakir et al reported that 5-year mortality in the general population of sickle cell anemia is $3.7 \%$, and $75 \%$ of patients aged 15 years or older survive 18 years or longer ( 9 ).

Significant renal involvement was not common, but microalbuminuria, enuresis and polyuria were the most common findings in our patients.

The development of chronic azotemia correlates strongly with poor prognosis and early mortality as compared to the general population of sickle cell anemia (9). GFR $<60$ was present in $5.2 \%$ of our patients while end stage renal disease was not present. GFR is usually increased in younger patients with sickle cell but it is typically reduced in older patients (5). A reversible renal concentrating defect in younger age groups can become irreversible in older patients. Vardaman et al stated increased total renal blood flow while medullary blood flow was probably decreased among young patients with sickle cell anemia (8). Also, Aygun reported that GFR was increased in SCD patients (10). In the patients $>16$ years, GFR decreased toward normal. In that study mean serum Cr was $0.3 \mathrm{mg} / 100 \mathrm{~mL}$ while serum Cystatin C was normal. Moreover Cystatin $\mathrm{C}$ was higher in those with lower GFR and higher levels of proteinuria. This is consistent with our findings (6). In contrast to defects in distal nephron abnormalities, proximal tubular functions were found to be supernormal. This is evidenced by an increased reabsorption of phosphorus and beta2-microglobulins and increased secretion of uric acid and $\mathrm{Cr}$. Alterations in renal hemodynamics were noted in SCD and S $\beta$ patients; but not 
Table 2. Frequency of Prehypertension and Hypertension in Patients with Sickle Syndrome

\begin{tabular}{|c|c|c|c|c|c|}
\hline \multirow[t]{2}{*}{ Blood Pressure Status, n (\%) } & \multirow[t]{2}{*}{ Total, $\mathbf{n}=\mathbf{9 7}$} & \multicolumn{3}{|c|}{ Study Groups } & \multirow[t]{2}{*}{ PValue } \\
\hline & & Sickle Thalassemia, $n=36$ & Sickle Trait, $\mathbf{n}=\mathbf{3 1}$ & Sickle Cell Disease, $\mathbf{n}=\mathbf{3 0}$ & \\
\hline Systolic prehypertension & $2(2.1)$ & $1(2.8)$ & $0(0.0)$ & $1(3.3)$ & 0.621 \\
\hline Systolic hypertension & $5(5.2)$ & $1(2.8)$ & $4(12.9)$ & $0(0.0)$ & 0.758 \\
\hline Diastolic prehypertension & $16(16.5)$ & $7(19.4)$ & $6(19.4)$ & $3(10.0)$ & 0.756 \\
\hline Diastolic hypertension & $6(6.3)$ & $4(11.1))$ & $0(0.0)$ & $2(6.7)$ & 0.192 \\
\hline
\end{tabular}

Table 3. Frequency of Urinary Symptoms in Patients with Sickle Syndrome

\begin{tabular}{|c|c|c|c|c|c|}
\hline \multirow[t]{2}{*}{ Symptoms, n (\%) } & \multirow[t]{2}{*}{ Total, $\mathbf{n}=\mathbf{9 7}$} & \multicolumn{3}{|c|}{ Study Groups } & \multirow[t]{2}{*}{ P Value } \\
\hline & & Sickle Thalassemia, $n=36$ & Sickle Trait, $\mathbf{n}=\mathbf{3 1}$ & Sickle Cell Disease, $n=30$ & \\
\hline Hematuria & $1(1.0)$ & $0(0.0)$ & $0(0.0)$ & $1(3.3)$ & $0.309^{\mathrm{a}}$ \\
\hline Polydipsia & $41(42.3)$ & $18(50.0)$ & $12(38.3)$ & $11(36.7)$ & 0.490 \\
\hline Polyuria & $19(19.6)$ & $6(16.7)$ & $6(20.0)$ & $7(23.0)$ & 0.795 \\
\hline Frequency & $5(5.2)$ & $1(2.8)$ & $2(6.5)$ & $2(6.7)$ & 0.605 \\
\hline Enuresis & $20(20.6)$ & $5(15.6)$ & $7(24.1)$ & $8(30.8)$ & 0.389 \\
\hline Nocturia & $30(30.9)$ & $10(31.3)$ & $9(31.0)$ & $11(42.3)$ & 0.732 \\
\hline Dysuria & $5(5.2)$ & $0(0.0)$ & $1(3.2)$ & $4(13.3)$ & 0.832 \\
\hline
\end{tabular}

${ }^{\mathrm{a}}$ Fisher exact test

in subjects with the SA. Mechanism of increased GFR and renal plasma flow in patients with SCD is related to compensatory hypersecretion of vasodilator prostaglandins in response to sickling $(5,11,12)$. During adolescence both GFR and RPF are normal, but are frequently subnormal after the age of 40. Progressive renal insufficiency in these patients has been ascribed to hyperfiltration-mediated sclerosis of the glomerular capillaries (13). In a more recent study, Schmitt et al, found enhanced macromolecule trafficking, decreased glomerular size selectivity, and at later stages, the reversible changes are no longer detected, and even a decrease in Kf may contribute to the decrease in GFR (14).

Significant proteinuria in the form of nephrotic syndrome, most often caused by sickle glomerulopathy, occurs in $4 \%$ of patients with sickle cell anemia, leading to renal failure in $2 / 3$ and death during 2 years in half of the patients (5). However, in the present study proteinuria was not found. The rate of microalbuminuria was similar to the reports of Becton et al (9), but less than reports of Imuetiyan et al, Lenensburger et al, and King (15-17). It is expected that micro-albuminuria is increased by aging and decreasing GFR $(10,18)$.

In spite of the fact that these patients are prone to recurrent severe infections, dehydration and exposure to potential nephrotoxic agents, similar to our finding the reported incidence of severe kidney injury in patients with SCD requiring renal replacement therapy is surprisingly low $(1,2)$. Papillary necrosis and infarction are wellrecognized findings in patients with SCD, as the risk of sickling is increased by the milieu of vascular congestion, relative sickle cell kidney hypoxia, hypertonicity and low $\mathrm{pH}$ in the renal medulla (19).

Due to the hypoxic, acidotic, and hyperosmolar environment of the inner medulla, sickling of erythrocytes with resultant impairment in renal medullary blood flow, ischemia, micro infarct, and papillary necrosis is promoted. Clinically, patients demonstrate an inability to concentrate urine $(5,20)$. In our study the rate of enuresis and nocturia was high. The rate of enuresis was high in the sickle cell anemia (30.8\%); moderate in SA (24.1\%); and lower in $\mathrm{S} \beta$ patients (15.6\%). Rate of nocturia was higher in patients with sickle cell anemia $(42.3 \%)$ but similar in SA and $\mathrm{S} \beta$ patients (31\%). This was expected by considering the above explained pathophysiologic changes. It has been shown in the previous studies that in young children with sickle cell anemia, maximal urine osmolality can be increased by multiple blood transfusions (21). However, with repeated thrombosis, progressive infarction, and necrosis of the papillae and inner medulla, the capacity to improve 
Table 4. Distribution of Some Renal Characteristics in Patients with Sickle Syndrome

\begin{tabular}{|c|c|c|c|c|c|}
\hline \multirow[t]{2}{*}{ Symptoms, n (\%) } & \multirow[t]{2}{*}{ Total, $\mathbf{n}=\mathbf{9 7}$} & \multicolumn{3}{|c|}{ Study Groups } & \multirow[t]{2}{*}{ P Value } \\
\hline & & Sickle Thalassemia, $n=36$ & Sickle Trait, $\mathbf{n}=31$ & Sickle Cell Disease, $\mathbf{n}=\mathbf{3 0}$ & \\
\hline Specific gravity & $1.013 \pm 0.04$ & $1.013 \pm 0.04$ & $1.014 \pm 0.05$ & $1.012 \pm 0.004$ & 0.178 \\
\hline Serum cratinine & $0.5 \pm 0.1$ & $0.5 \pm 0.1$ & $0.6 \pm 0.1$ & $0.5 \pm 0.2$ & $0.016^{\mathrm{a}}$ \\
\hline Serum Cystatine C & $0.9 \pm 0.2$ & $1.0 \pm 0.2$ & $0.9 \pm 0.3$ & $0.8 \pm 0.2$ & $0.007^{\mathrm{b}}$ \\
\hline GFR by Cystatine C & $86.9 \pm 21.5$ & $77.2 \pm 12.8$ & $91.3 \pm 22.3$ & $94.1 \pm 24.9$ & $0.002^{+}$ \\
\hline Proteinuria & $0(0.0)$ & $0(0.0)$ & $0(0.0)$ & $0(0.0)$ & - \\
\hline Microalbuminuria & $14(14.4)$ & $5(13.9)$ & $5(13.9)$ & $4(13.3)$ & 0.946 \\
\hline Hypercalciuria & $16(16.5)$ & $6(16.7)$ & $2(6.5)$ & $8(26.7)$ & 0.104 \\
\hline
\end{tabular}

${ }^{\mathrm{a}}$ LST test as a post hoc test showed: sickle trait group had higher cratinine than the other groups $(\mathrm{P}<0.003)$.

${ }^{b}$ LST test as a post hoc test showed: sickle trait group had higher Cystatine $\mathrm{C}$ than the other groups $(\mathrm{P}<0.004)$. + LST test as a post hoc test showed: sickle trait group had higher GFR than the other groups $(\mathrm{P}<0.001)$.

renal concentrating ability is progressively lost with age, and the defect is irreversible after the age of 15 (21). Unexpectedly in our patients there was a significant negative correlation between age and urine concentration, so that mean age of 8 patients who had urine specific gravity $<1.005$ was $6.05 \pm 1.8$ years; while it was $8.97 \pm 3.45$ in patients who had urine specific gravity $>1.005$. This was against the expected progressive loss of urine concentrating ability with increasing age. It may be in part explained by physicians encouraging the patients for increasing water intake in smaller children and their compliance may be better than teenagers.

Idiopathic hypercalciuria was not previously reported in sickle syndrome. Hypercalciuria predisposes the patients to renal stone and may be the cause of different urinary symptoms (22), including vasopressin resistant diabetes insipidus (23). Hypercalciuria was detected in $16.5 \%$ of our patients and only $2 \%$ had history of renal stone. Hematuria which is more prevalent in thalassemia major patients in this center (24) was unexpectedly infrequent in our patients with sickle syndrome. Susceptibility to malignancy in cases of hemoglobinopathy which was previously reported in sickle cell anemia $(25,26)$ was not detected in our patients.

These findings need to be the subject of more detailed study in future and preferably within a cohort study.

\subsection{Conclusion}

In contrast to other reports, significant renal complications including renal failure and proteinuria were unusual in our patients with sickle cell syndrome at least in the first two decades of life.

\section{Acknowledgments}

This study was done by grant 1392/4216 from research affair of Shiraz University of Medical Sciences, as partial fulfillment of requirements for the degree of subspecialty in pediatric nephrology by Dr. Sayyed Yousef Mojtahedi.

\section{Footnote}

Funding/Support: The vice-chancellery of research and technology of Shiraz University of Medical Sciences financially supported this study (grant 1392/4216).

\section{References}

1. Brandow AM, Liem R. "Sickle Cell Disease in the Emergency Department: Atypical Complications and Management". Clin Pediatr Emerg Med. 2011;12(3):202-12. doi: 10.1016/j.cpem.2011.07.003. [PubMed: 21927581].

2. Bruno D, Wigfall DR, Zimmerman SA, Rosoff PM, Wiener JS. Genitourinary complications of sickle cell disease. J Urol. 2001;166(3):803-11. [PubMed: 11490223].

3. Ataga KI, Orringer EP. Renal abnormalities in sickle cell disease. Am J Hematol. 2000;63(4):205-11. [PubMed:10706765].

4. Becton LJ, Kalpatthi RV, Rackoff E, Disco D, Orak JK, Jackson SM, et al. Prevalence and clinical correlates of microalbuminuria in children with sickle cell disease. Pediatr Nephrol. 2010;25(8):1505-11. doi: 10.1007/s00467-010-1536-8. [PubMed: 20505954].

5. Gargiulo R, Pandya M, Seba A, Haddad RY, Lerma EV. Sickle cell nephropathy. Dis Mon. 2014;60(10):494-9. doi: 10.1016/j.disamonth.2014.08.004. [PubMed: 25282510].

6. Sharpe CC, Thein SL. Sickle cell nephropathy - a practical approach. Br J Haematol. 2011;155(3):287-97. doi: 10.1111/j.1365-2141.2011.08853.x. [PubMed: 21902687].

7. Nasr SH, Markowitz GS, Sentman RL, D’Agati VD. Sickle cell disease, nephrotic syndrome, and renal failure. Kidney Int. 2006;69(7):127680. doi:10.1038/sj.ki.5000234. [PubMed:16482096].

8. Vardaman M, Buckalew J, Ayten S. Renal manifestations of sickle cell disease. Arch Intern Med. 1974;133(4):660-9. 
9. Bakir AA, Hathiwala SC, Ainis H, Hryhorczuk DO, Rhee HL, Levy PS, et al. Prognosis of the nephrotic syndrome in sickle glomerulopathy. A retrospective study. Am J Nephrol. 1987;7(2):110-5. [PubMed:3605231].

10. Aygun B, Mortier NA, Smeltzer MP, Hankins JS, Ware RE. Glomerular hyperfiltration and albuminuria in children with sickle cell anemia. Pediatr Nephrol. 2011;26(8):1285-90. doi: 10.1007/s00467-011-18572. [PubMed: 21559933].

11. Silva Junior GB, Vieira AP, Couto Bem AX, Alves MP, Meneses GC, Martins AM, et al. Renal tubular dysfunction in sickle cell disease. Kidney Blood Press Res. 2013;38(1):1-10. doi: 10.1159/000355748. [PubMed: 24504378].

12. Badr M, El Koumi MA, Ali YF, El-Morshedy S, Almonem NA, Hassan $\mathrm{T}$, et al. Renal tubular dysfunction in children with sickle cell haemoglobinopathy. Nephrology (Carlton). 2013;18(4):299-303. doi: 10.1111/nep.12040. [PubMed: 23432792].

13. Vazquez B, Shah B, Zhang X, Lash JP, Gordeuk VR, Saraf SL. Hyperfiltration is associated with the development of microalbuminuria in patients with sickle cell anemia. Am J Hematol. 2014;89(12):1156-7. doi: 10.1002/ajh.23817. [PubMed: 25132221].

14. Schmitt F, Martinez F, Brillet G, Giatras I, Choukroun G, Girot R, et al. Early glomerular dysfunction in patients with sickle cell anemia. Am J Kidney Dis. 1998;32(2):208-14. [PubMed: 9708603].

15. Imuetinyan BA, Okoeguale MI, Egberue GO. Microalbuminuria in children with sickle cell anemia. Saudi J Kidney Dis Transpl. 2011;22(4):7338. [PubMed: 21743219].

16. Lebensburger J, Johnson SM, Askenazi DJ, Rozario NL, Howard TH, Hilliard LM. Protective role of hemoglobin and fetal hemoglobin in early kidney disease for children with sickle cell anemia. Am J Hematol. 2011;86(5):430-2. doi: 10.1002/ajh.21994. [PubMed: 21523807].

17. King L, MooSang M, Miller M, Reid M. Prevalence and predictors of mi- cro albuminuria in Jamaican children with sickle cell disease. Arch Dis Child. 2010;96(12):1135-9.

18. Mawanda M, Ssenkusu JM, Odiit A, Kiguli S, Muyingo A, Ndugwa C. Micro-albuminuria in Ugandan children with sickle cell anaemia: a cross-sectional study. Ann Trop Paediatr. 2011;31(2):115-21. doi: 10.1179/1465328111Y.0000000013. [PubMed: 21575315].

19. Davenport A, Buscombe J. Sickle cell kidney. J Nephrol. 2008;21(2):2535. [PubMed: 18446721].

20. Fabry ME, Costantini F, Pachnis A, Suzuka SM, Bank N, Aynedjian HS, et al. High expression of human beta S- and alpha-globins in transgenic mice: erythrocyte abnormalities, organ damage, and the effect of hypoxia. Proc Natl Acad Sci US A. 1992;89(24):12155-9. [PubMed:1465455]

21. Pham PT, Pham PC, Wilkinson AH, Lew SQ. Renal abnormalities in sickle cell disease. Kidney Int. 2000;57(1):1-8. doi: 10.1046/j.15231755.2000.00806.x. [PubMed: 10620181].

22. Fallahzadeh MK, Fallahzadeh MH, Mowla A, Derakhshan A. Hypercalciuria in children with urinary tract symptoms. Saudi J Kidney Dis Transpl. 2010;21(4):673-7. [PubMed: 20587871].

23. Fallahzadeh MH.Vasopressin resistant diabetes insipidus in a patient with idiopathic hypercalciuria. IJMS. 1994;19(3):160-2.

24. Fallahzadeh MH, Fallahzadeh MK, Shahriari M. Prevalence of hematuria in patients with beta thalassemia major. IJKD. 2010;4:33-6.

25. Shahriari M, Haghpanah S, Dehghani J, Dehbozorgian J, Eatemadfar P, Bazrafshan A, et al. Serum cancer antigen 15.3 concentrations in patients with betathalassemia minor compared to those with cancer and healthy individuals. Med J Islam Repub Iran. 2014;28:91. [PubMed: 25664292]

26. Shahriari M, Alidoost HR. The protective effect of $\beta$-thalassemia trait against childhood malignancies in an unselected Iranian population. Middle East J Cancer. 2011;2(1):27-30. 